\title{
Incorporating Ethics and Professionalism into Environmental Engineering Curriculum
}

\section{Dr. Ramanitharan Kandiah P.E., Central State University}

Associate Professor of Environmental Engineering, International Center for Water Resources Management, Central State University, Wilberforce, Ohio. He is a co-author of the textbook, 'Introduction to Water Resources'. He holds a PhD in Civil Engineering from Tulane University and a registered Professional Civil Engineer in Ohio.

\section{Prof. Krishna Kumar V Nedunuri, International Center for Water Resources}

Dr. Nedunuri is the Director of the International Center for Water Resources Management. He is also the Chairperson/Professor of Water Resources Management and Environmental Engineering at Central State University, Wilberforce, Ohio. He holds a $\mathrm{PhD}$ in the area of Hydraulics and Environmental Engineering from Purdue University. He co-authored a textbook titled 'Introduction to Water Resources' published by Kendall Hunt.

\section{Dr. Ning Zhang, Central State University}

Dr. Ning Zhang currently is an assistant professor at Central State University. Dr. Zhang holds a Ph.D. degree in Environmental Engineering from West Virginia University. She has expertise in physical and chemical processes for water and wastewater treatment. Her research interests are water/wastewater treatment technology development, water quality monitoring, environmental risk assessment, and environmental sustainability. Courses taught by her including environmental engineering, water resources engineering, water chemistry, and limnology. 


\title{
Incorporating Ethics and Professionalism into Environmental Engineering Curriculum
}

\begin{abstract}
Ethics is a vital component and compass in any profession. In engineering, in the recent years, the importance of ethics has been stressed more than ever. While the state licensure bodies monitor the professional conduct of the engineers, professional engineering bodies insist and expect their members to have good moral character and ethical integrity. This professional requirement also calls on the engineering educators to develop the engineering curriculum enriched with ethics and professionalism.
\end{abstract}

An engineering undergraduate can passively learn professionalism and ethics through senior capstone design, summer internships and undergraduate research. However, these opportunities have limitations. Hence, as the instructors in an engineering program, the authors felt more on the formal teaching and practice on ethics and professional conduct needed to raise the awareness in accordance with ABET Student Outcomes- $f$ and $i$, and the professional body expectations. Environmental engineering curriculum in the authors' institution introduces ethics and professionalism to the students primarily through two one-credit hour semester courses, First Year Seminar I and Environmental Professional Seminar.

This paper presents the evolution of the course, Environmental Professional Seminar and the other indirect methods to enhance the understanding and practice of ethics and professionalism in engineering students. The enhancement is still an ongoing process as few recommendations from last assessment of these two courses will only be implemented in Fall 2017.

Introduction

Ethics is a vital component and compass to any profession. In engineering, the importance of ethics has been stressed in recent years more than ever. In the aftermath of Flint water crisis and Volkswagen emission scandal, Ethics and Professionalism (E\&P) in engineering and science has become much discussed topic in the industry and also in the academia (Detroit Free Press, 2016; Burke, 2016). While the state licensure bodies monitor the professional conduct of the engineers, professional engineering bodies like National Society of Professional Engineers (NSPE) and American Society of Civil Engineers (ASCE) insist and expect their members to have good moral character and ethical integrity (NSPE, 2016; ASCE, 2012).

However, the ethical contact and the professionalism of an engineer do not start with the engineer's first assignment as a graduate engineer, but with what this individual learns in classrooms as an engineering student and how s|he gets trained as an engineering intern. The seeds of ethics and professionalism should be sown in the universities with classroom teaching, and guidance, and through industrial mentorship. The Accreditation Board of Engineering and Technology (ABET) that evaluates and accredits engineering programs re-emphasized this fact in the post-Flint water and post-Volkswagen emission era (ABET, 2016). 
Flint water and Volkswagen emission incidents show that there is an urgent need to include E\&P concepts into new engineering curricula and to raise the awareness further on E\&P by enhancing existing curricula. However, given the limitations on maximum allowable credit hours in a four year engineering program and the requirements to satisfy a minimum number of general education courses in addition to engineering pre-requisites and core engineering courses, it is always a challenge to include a three credit hour per semester course on ethics and professional conduct. This reality calls for innovative ways to inject concepts and practice of ethics and professionalism in the engineering curricula without compromising the quality of core engineering courses and|or in the expense of a core engineering course.

\section{Ethics and professionalism}

For the general purpose, ethics can be described as a set of defined moral principles that guides the practice of a profession on what is good and bad and with moral duty and obligation. The strict definition and guidelines of engineering ethics for an engineer are given by the revised Code of Ethics for Engineers of NSPE (NSPE, 2007). The essence of ethics for engineers can be summarized with the Code of Ethics for Engineers as, “...the services provided by engineers require honesty, impartiality, fairness, and equity, and must be dedicated to the protection of the public health, safety, and welfare.”

The professionalism in general can be summarized as the characteristics that a society requires from a professional in the professional's conduct, aims, or qualities in connection with the profession. In the engineering context, this can be elaborated as an engineer's ability to act quickly, thoroughly, adaptively, levelheadedly and effectively in the ever-changing organizational structure on a challenging task to fulfil the client requirements with the high caliber engineering and technological service without failing the defined policies and binding regulations.

A practicing engineer can frequently take opportunities to keep herself or himself updated with the ever-changing policies and regulations or to refresh the E\&P through the mandatory continuing education required by the state engineering licensure boards for keeping her or his professional engineer status active. A professional engineer is also scrutinized by the state engineering board for her or his professional and ethical conducts during the renewal of the license. As the counterpart, in the academic environment, an engineering student who prepares for the future engineering practice is taught with an engineering curriculum that is prepared and frequently assessed for its adherence to the ABET-Student Outcomes $f$ - An understanding of professional and ethical responsibility and $i$ - A recognition of the need for, and ability to engage in life-long learning defined by the Engineering Accreditation Commission. This curriculum has also to satisfy the expectations of environmental engineering professional societies such as ASCE and American Academy of Environmental Engineers and Scientists (AAEES) with respect to $\mathrm{E} \& \mathrm{P}$.

At the authors' institution, the following performance indicators are identified to assess the student outcomes $f$ and $i$ (Table 1). 
Table 1: Performance indicators for ABET student outcomes $f$ and $i$

\begin{tabular}{|l|l|l|}
\hline Outcome & \multicolumn{3}{|l|}{ Performance Indicator } \\
\hline$f$ & $f 1$ & Knows code of ethics for the profession \\
\cline { 2 - 3 } & $f 2$ & Evaluates ethical dimensions of issues that may occur in professional practice \\
\cline { 2 - 3 } & $f 3$ & Interacts with others in the community in a professional manner. \\
\hline \multirow{3}{*}{$i$} & $i 1$ & Able to use resources to learn new materials without guidance \\
\cline { 2 - 3 } & $i 2$ & Seeks sources for continuing education purposes \\
\cline { 2 - 3 } & $i 3$ & Accepts personal responsibility for learning \& of the importance of life-long learning \\
\hline
\end{tabular}

Environmental engineering program

Undergraduate Environmental Engineering (ENE) program at the authors' institution graduated its first batch in 2011. For an ENE student, the formal learning and experiences on ethics and professionalism are channeled through the following:

1. Course work

2. Internship and work experiences

3. Undergraduate research

4. Other service related tasks through student societies and organizations

Course work and internship experiences are directly connected to class assessment on student's knowledge and practice of ethics and professionalism. Undergraduate research and other services are used as indirect evaluation tools that do not reflect in the transcripts, but are measured and summarized with a student's research publications and presentations, and service activities.

\section{Course work}

While across the ENE curriculum, some E\&P concepts such as consequences of plagiarism, attendance, punctuality, adhering to the deadlines and individual responsibilities in group activities are incorporated in all courses, two courses are exclusively designed and enriched with the E\&P concepts: Freshman Seminar I (FYS) at the freshman level and Environmental Professionals Seminar (EPS) in the junior/senior level.

FYS is a general education course that systematically introduces the independent and educationally and socially demanding campus life to a high school graduate and transforms her/him into a responsible freshman. It also intends to guide and prepare the freshman for her/his major field of education and its requirements and expectations. Until Fall 2015, this course was taught by non-engineering faculty to the ENE students. However, in the advising sessions with the ENE freshmen and sophomores, the ENE professors felt that more work was needed on preparing a freshman for an engineering program, thus for an engineering career. These needed areas include responsibility, critical thinking and work ethics. Two of the authors currently address this issue as an objective of a funded National Science Foundation grant (NSF Award\#1565049). In Fall 2016, a FYS session was held by the second author mainly for engineering majors (environmental engineering and manufacturing engineering) and for other STEM majors addressing issues that are specific to engineering and other STEM careers. 
Appendix-A provides the assessment summary for this class. The authors will assess the effectiveness of this course with respect to E\&P in Fall 2017.

The flagship course for teaching E\&P, Environmental Professional Seminar, a one-credit hour semester course is offered once or twice in a year for juniors/seniors. The course description from the 2014 university catalog is given below.

Presentations by guest speakers, professional agencies, and internal or external faculties on current topics and issues within the areas of environmental engineering (water/wastewater restoration, water resources management, environmental regulations, air pollution and control, hazardous waste management, engineering professional development and etc.) will be given in this course. Students will also be assigned with literature readings regarding contemporary environmental issues. Some discussions on the assigned literatures might be expected in class. A summary of each guest presentation and literature reading is required.

In the period of 2010-2016, the EPS course was assessed three times (Fall 2010, Fall 2012 and Spring 2016), and the learning outcomes and the assessment tools were updated to enhance the student learning experience and the needs of the industry (for practicing engineers) and the academia (graduate engineering students). The Instructor Course Reports (ICR) that provide the assessment rubrics, findings and recommendations for the course for the years of 2010 and 2016 are presented in Appendix- $B$ and Appendix- $C$ respectively.

In 2010, the guest speakers from the industry and academia presented various topics in design, engineering, technology, management, legislation and research. Speakers discussed these principles as they are advocated within the industry and challenges in enforcing them. The students were asked to submit reviews of these talks which were assessed by the instructor. The presentations were on five academic research topics such as Stream - Aquifer Interaction Assessment Using Riparian Evapotranspiration Estimates from Remote Sensing Algorithms, three industrial topics such as Industrial Waste Management and Environmental Engineering careers, and two on local and federal government agencies such as Careers in NRCS and Regional Air Pollution Control Agency \& Ambient Air Quality Monitoring. Appendix-B provides the assessment summary for EPS Fall 2010.

However, to engage the students more and to include additional E\&P issues into the course, the instructors felt a need for a more traditional lecture based approach. Hence, in 2016, as the new components, reviews on ethical case studies and exams were added to the course. Also, the graduates from the same ENE program, who currently work in the industry and the government were invited as the guest speakers to provide the students their insights and the experiences. With the Fall 2016 assessment (Appendix-C), in the capacity of the instructor, the first author recommended to incorporate two more components, project management and research conduct into EPS course with the experiences gained from other courses. Project management was found as a required topic from the course, Senior Capstone Project. Engineering students doing undergraduate research at the authors' institution have to pass an online training course on Responsible Conduct of Research for Engineers (RCRE) administered and assessed by Collaborative Institutional Training Initiative (CITI). While this training course is useful in 
learning ethics and professional conduct, it is currently limited to those students performing undergraduate research. Hence, it was decided to add as a part of EPS in the future.

Table 2a and Table 2b show the learning outcomes and the assessment tools for the years 2010 and 2017 (proposed). Table 3a and Table 3b show the grading system for the years 2010 and 2017 (proposed).

Table 2a. Learning outcomes and assessment tools for EPS in 2010

\begin{tabular}{|l|l|}
\hline \multicolumn{1}{|c|}{ Course Outcomes } & \multicolumn{1}{c|}{ Learning Measure } \\
\hline $\begin{array}{l}\text { CO-1: Be familiar with practical engineering operations } \\
\text { in professional setup }\end{array}$ & $\begin{array}{l}\text { Lectures, Guest Presentation, } \\
\text { Reading Assignments }\end{array}$ \\
\hline $\begin{array}{l}\text { CO-2: Expose to recent engineering challenges and } \\
\text { concerns }\end{array}$ & $\begin{array}{l}\text { Lectures, Guest Presentation, } \\
\text { Reading Assignments }\end{array}$ \\
\hline CO-3: Prepare students for future career development & $\begin{array}{l}\text { Lectures, Guest Presentation, } \\
\text { Reading Assignments }\end{array}$ \\
\hline
\end{tabular}

Table 2a. Learning outcomes and assessment tools for EPS proposed for Fall 2017

\begin{tabular}{|l|l|}
\hline \multicolumn{1}{|c|}{ Learning Outcome } & \multicolumn{1}{c|}{ Assessment Instrument } \\
\hline $\begin{array}{l}\text { CO-1: Be familiar with practical engineering operations } \\
\text { in professional setup and management* }\end{array}$ & $\begin{array}{l}\text { Lectures, Guest Presentation, Reading } \\
\text { Assignments, Gantt Chart* }\end{array}$ \\
\hline CO-2: Develop engineering philosophy and ethics & $\begin{array}{l}\text { Lectures, Ethics Online Module*, } \\
\text { Case Studies, Reading Assignments, } \\
\text { Final Exam }\end{array}$ \\
\hline CO-3: Learn to apply theoretical knowledge to practice & $\begin{array}{l}\text { Lectures, Homework, In-Class } \\
\text { Discussions, final exam }\end{array}$ \\
\hline $\begin{array}{l}\text { CO-4: Expose to recent engineering challenges and } \\
\text { concerns }\end{array}$ & $\begin{array}{l}\text { Lectures, Guest Presentation, In-Class } \\
\text { Discussions, final exam }\end{array}$ \\
\hline CO-5: Prepare students for future career development & $\begin{array}{l}\text { Lectures, Case Studies, Reading } \\
\text { Assignments, Videos }\end{array}$ \\
\hline
\end{tabular}

* Proposed changes for Fall 2017 class from the assessment from Fall 2016 class

Table 3a. Grading system for EPS in 2010

\begin{tabular}{|l|c|}
\hline Attendance and Class Participation & $30 \%$ \\
\hline Reports and Reviews & $70 \%$ \\
\hline
\end{tabular}

Table 3b. Grading system for EPS proposed for Fall 2017

\begin{tabular}{|l|c|}
\hline Attendance and Class Participation & $10 \%$ \\
\hline Seminar Review & $25 \%$ \\
\hline Responsible Conduct of Research for Engineers: CITI Module* & $5 \%$ \\
\hline Reading Assignment and Paper/Documentary Review & $20 \%$ \\
\hline In-Class Discussions & $10 \%$ \\
\hline Case studies & $10 \%$ \\
\hline Final examination & $20 \%$ \\
\hline
\end{tabular}

* Proposed change for Fall 2017 class from the assessment from Fall 2016 class 
The instructors also plan to make a three credit hour humanities and fine arts course Applied Ethics as a mandatory general education course for the ENE program as it could reinforce E \& P. The course description from the 2016-2017 university catalog is given below:

Students apply ethical theory to a range of contemporary personal, social, and professional issues. The role of ethics in community life is explored and the sources of values, norms and principles are investigated.

Internship and other work experiences

The courses, Senior Capstone Project I (SCP-I), Senior Capstone Project II (SCP-II), and Summer Internship (SI) partially or indirectly mimic or provide experiences for the students at they would have in a real workplace. SCP-I and SCP-II mimic the work environment with a "designation|position" for each student in the project team that allows the student be responsible for sub-projects and specific tasks. It aids the students in developing program management skills via the experience in Gantt Charts, following the protocol, communication skills and the time management (keeping punctuality and honoring deadlines). Some of these components are used in evaluating the students for this course.

Although only one summer long internship experience is expected from the students as the program requirement, the students usually do at least two. Students are currently expected to submit a report at the end of their internships to the instructor for grades, and also are expected to present their experiences in the future EPS classes - especially on the aspects of E\&P expected in the industry or in the government. In the future, the second author, who is also the instructorliaison for the internships wants to develop an assessment scheme to grade the course based on feedback from the employers for the summer internships on students' work ethics, professionalism and the technical knowledge.

\section{Undergraduate Research}

Few ENE students involve in funded research under the supervision of ENE faculty. While the research mentor-faculty guides and trains the students, the faculty also expects them to aware of the research ethics. Currently, any student wants to involve in research has to take the online course, RCRE of CITI before engaging in the research. As it has been explained earlier, this online training will be expanded for all EPS students.

Other service related tasks through student societies and organizations

Some of the ENE students are part of the national societies such as National Society of Black Engineers (NSBE) student chapter, and Minorities in Agriculture, Natural Resources and Related Sciences (MANRRS), and the other local organizations including Water Resources and Environmental Engineering club. They also help the faculty in professional and recruitment events. While these activities do not directly help them to get a grade, the experiences certainly help them to learn the protocols and other managerial, social and professional skills they need, and help the faculty in assessing the students on E\&P. 
Conclusions and Acknowledgement

Awareness on ethics and professionalism should co-start with the learning of the trade itself. Hence, the engineering teaching institutions hold a big responsibility in their hands. The engineering curriculum should give enough consideration for adding and assessing topics on ethical and professional conducts in their curriculum. Incorporating ethics and professionalism into environmental engineering curriculum is a continuing process that has to be furnished with the contemporary issues and with the enhancement of teaching and learning tools.

The authors want to thank National Science Foundation - Division Of Undergraduate Education (Award\#1565049) for sparking an idea for an exclusive First Year Seminar course for engineering majors and supporting some of the ENE majors through this grant. They also want to thank all the guest speakers from the industry, academia and government for the presentations for the course, Environmental Professionals Seminar.

References

1. ABET. 2016. Teaching Ethics in Light of Flint and Volkswagen. June 26, 2016 http://www.abet.org/blog/news/flint-volkswagen-and-teaching-ethics/

2. ASCE. 2012. The ASCE Code of Ethics: Principles, Study, and Application. 25 pp. http://www.asce.org/uploadedFiles/About_ASCE/Ethics/Content_Pieces/ASCE-CodeOf-Ethics-2012-FINAL-HIGH.pdf

3. Burke, K. L. 2016. Flint Water Crisis Yields Hard Lessons in Science and Ethics, American Scientist. May-June 2016, 104(3) http://www.americanscientist.org/issues/pub/flint-water-crisis-yields-hard-lessons-inscience-and-ethics

4. Detroit Free Press. 2016. How Volkswagen, Flint speak to regulatory deficiencies. June 29, 2016. http://www.freep.com/story/opinion/columnists/stephenhenderson/2016/06/29/how-volkswagen-flint-speak-regulatory-deficiencies/86529318/

5. NSPE. 2007. The Code of Ethics. NSPE Publication \#1102 July 2007. 2 pp. https://www.nspe.org/sites/default/files/resources/pdfs/Ethics/CodeofEthics/Code-2007July.pdf

6. NSPE. 2016. The NSPE: Ethics References Guide. NSPE Publication \#1107 April 2016. $25 \mathrm{pp}$. https://www.nspe.org/sites/default/files/resources/pdfs/Ethics/EthicsReferenceGuide.pdf

APPENDIX - A

\section{Instructor Course Report (ICR) for Fall 2016}

\begin{tabular}{|l|l|}
\hline Course & FYS 1100, First Year Seminar \\
\hline Term/Year & Fall 2016 \\
\hline Faculty & \\
\hline
\end{tabular}

To measure performance, use the scales, U: Unsatisfactory, D: Developing, S: Satisfactory, and E: Excellent

$$
\mathrm{E} \geq 90 \%, \quad 75 \% \leq \mathrm{S}<90 \%, \quad 60 \% \leq \mathrm{D}<75 \% \text { and } \mathrm{U}<60 \%
$$


To measure outcome attainment level, use the following scale with the points assigned as $\mathbf{E}=5, \mathrm{~S}=\mathbf{3}, \mathbf{D}=\mathbf{2}$ and $\mathbf{U}=\mathbf{0}$

\begin{tabular}{|l|l|l|}
\hline $\begin{array}{l}\text { AVG (5 points } \\
\text { max) }\end{array}$ & $\begin{array}{l}\text { Equivalent } \\
\text { Percentage }\end{array}$ & Recommendations \\
\hline $\mathrm{AVG} \geq 3.50$ & $\mathrm{AVG} \geq 70 \%$ & Met, no action \\
\hline $3.00 \leq \mathrm{AVG}<3.50$ & $60 \leq \mathrm{AVG}<70 \%$ & Mostly met, check conditions \\
\hline $2.50 \leq \mathrm{AVG}<3.00$ & $50 \leq \mathrm{AVG}<60 \%$ & Partially met, check conditions, analyze for correction \\
\hline $\mathrm{AVG}<2.50$ & $\mathrm{AVG}<50 \%$ & Not met, analyze and take action \\
\hline
\end{tabular}

Notes: The total enrollment in this class was 26 students.

Grade distribution:

\begin{tabular}{|l|l|l|l|l|l|l|}
\hline A & B & C & D & F & FZ & Total \\
\hline 3 & 3 & 6 & 6 & 7 & 1 & 26 \\
\hline
\end{tabular}

ABET Student Outcomes

\begin{tabular}{|l|l|c|c|c|c|c|l|}
\hline $\begin{array}{l}\text { Performance } \\
\text { Indicator }\end{array}$ & $\begin{array}{c}\text { Student Learning } \\
\text { Measure }\end{array}$ & $\mathbf{E}$ & $\mathbf{S}$ & $\mathbf{D}$ & $\mathbf{U}$ & AVG & Comments/Actions \\
\hline F1 & AS1,AS2,AS4,AS8 & 2.50 & 0.50 & 0.00 & 1.00 & 3.50 & met \\
\hline F2 & AS5,AS8 & 2.50 & 0.50 & 0.00 & 1.00 & 3.50 & met \\
\hline F3 & AS3,AS5,AS9 & 2.33 & 0.67 & 0.33 & 0.67 & 3.58 & met \\
\hline $\begin{array}{l}\text { F-Overall } \\
\text { Average }\end{array}$ & & $\mathbf{2 . 4 5}$ & $\mathbf{0 . 5 5}$ & $\mathbf{0 . 1 0}$ & $\mathbf{0 . 9 0}$ & 3.53 & met \\
\hline I1 & AS1,AS2 & 3.00 & 0.00 & 0.00 & 1.00 & 3.75 & met \\
\hline I2 & AS3,AS4,AS8,AS9 & 2.25 & 0.75 & 0.25 & 0.75 & 3.50 & met \\
\hline I3 & AS3,AS5,AS7 & 2.33 & 0.67 & 0.33 & 0.67 & 3.58 & met \\
\hline $\begin{array}{l}\text { I-Overall } \\
\text { Average }\end{array}$ & & $\mathbf{2 . 5 5}$ & $\mathbf{0 . 4 5}$ & $\mathbf{0 . 1 7}$ & $\mathbf{0 . 8 3}$ & 3.61 & met \\
\hline
\end{tabular}

Assignments AS1-AS9 include the topics on Profession, Role model, Advising, Time management, and Financial literacy.

\section{APPENDIX - B}

\section{Instructor Course Report (ICR) for Fall 2010}

\begin{tabular}{|l|l|}
\hline Course & ENE 4440, Environmental Professionals Seminar \\
\hline Term/Year & Fall 2010 \\
\hline Faculty & \\
\hline
\end{tabular}

To measure performance, use the scales, U: Unsatisfactory, D: Developing, S: Satisfactory, and E:

Excellent

$$
\mathrm{E} \geq 90 \%, \quad 75 \% \leq \mathrm{S}<90 \%, \quad 60 \% \leq \mathrm{D}<75 \% \text { and } \mathrm{U}<60 \%
$$

To measure outcome attainment level, use the following scale with the points assigned as $\mathbf{E}=5, S=3, D=2$ and $\mathbf{U}=\mathbf{0}$ 


\begin{tabular}{|l|l|l|}
\hline $\begin{array}{l}\text { AVG (5 points } \\
\text { max) }\end{array}$ & $\begin{array}{l}\text { Equivalent } \\
\text { Percentage }\end{array}$ & Recommendations \\
\hline $\mathrm{AVG} \geq 3.50$ & $\mathrm{AVG} \geq 70 \%$ & Met, no action \\
\hline $3.00 \leq \mathrm{AVG}<3.50$ & $60 \leq \mathrm{AVG}<70 \%$ & Mostly met, check conditions \\
\hline $2.50 \leq \mathrm{AVG}<3.00$ & $50 \leq \mathrm{AVG}<60 \%$ & Partially met, check conditions, analyze for correction \\
\hline $\mathrm{AVG}<2.50$ & $\mathrm{AVG}<50 \%$ & Not met, analyze and take action \\
\hline
\end{tabular}

Notes: The total enrollment in this class was 4 students.

Grade distribution:

\begin{tabular}{|l|l|l|l|l|l|l|}
\hline A & B & C & D & F & W & Total \\
\hline 2 & 1 & 1 & 0 & 0 & 0 & 4 \\
\hline
\end{tabular}

Course Outcomes

\begin{tabular}{|l|l|c|c|c|c|c|l|}
\hline \multicolumn{1}{|c|}{ Course Outcomes } & \multicolumn{1}{|c|}{$\begin{array}{c}\text { Learning } \\
\text { Measure }\end{array}$} & E & S & D & U & AVG & Attainment/Comments \\
\hline $\begin{array}{l}\text { CO-1: Be familiar with } \\
\text { practical engineering } \\
\text { operations in } \\
\text { professional setup }\end{array}$ & $\begin{array}{l}\text { PR2, PR9, } \\
\text { PR10 }\end{array}$ & 2.00 & 0.33 & 0.00 & 1.67 & 2.75 & Partially met \\
\hline $\begin{array}{l}\text { CO-2: Expose to recent } \\
\text { engineering challenges } \\
\text { and concerns }\end{array}$ & $\begin{array}{l}\text { PR1, PR3, PR4, } \\
\text { PR5 }\end{array}$ & 1.75 & 0.50 & 0.00 & 1.75 & 2.56 & Partially met \\
\hline $\begin{array}{l}\text { CO-3: Prepare students } \\
\text { for future career } \\
\text { development }\end{array}$ & PR7, PR10 & 1.50 & 0.50 & 0.00 & 2.00 & 2.25 & not met \\
\hline CO-Overall Average & & & & & & 2.52 & Partially met \\
\hline
\end{tabular}

ABET Student Outcomes

\begin{tabular}{|l|l|c|c|c|c|c|l|}
\hline $\begin{array}{l}\text { Performance } \\
\text { Indicator }\end{array}$ & $\begin{array}{c}\text { Student Learning } \\
\text { Measure }\end{array}$ & E & S & D & U & AVG & Comments/Actions \\
\hline F1 & PR7, PR10 & 1.50 & 0.50 & 0.00 & 2.00 & 2.25 & not met \\
\hline F2 & PR7, PR10 & 1.50 & 0.50 & 0.00 & 2.00 & 2.25 & not met \\
\hline F3 & PR2, PR9, PR10 & 2.00 & 0.33 & 0.00 & 1.67 & $\mathbf{2 . 7 5}$ & partially met \\
\hline $\begin{array}{l}\text { F-Overall } \\
\text { Average }\end{array}$ & & & & & & $\mathbf{2 . 4 2}$ & not met \\
\hline I1 & PR2, PR3 & 2.50 & 0.50 & 0.00 & 1.00 & $\mathbf{3 . 5 0}$ & met \\
\hline I2 & PR1, PR3 & 2.00 & 0.50 & 0.00 & 1.50 & $\mathbf{2 . 8 8}$ & partially met \\
\hline I3 & PR7, PR10 & 1.50 & 0.50 & 0.00 & 2.00 & $\mathbf{2 . 2 5}$ & not met \\
\hline $\begin{array}{l}\text { I-Overall } \\
\text { Average }\end{array}$ & & & & & & $\mathbf{2 . 8 8}$ & partially met \\
\hline
\end{tabular}

Faculty Evaluation:

While the course in Fall 2010 was resourceful for the students with number of guest speakers who presented in variety of environmental engineering topics, it was found that the course outcomes were only partially met and the targeted ABET Student Outcome $f$ was not met. The reason for this situation could have been the nonexistence of the formal introduction of the topics such as engineering profession, ethics, environmental impact assessment and other management topics. It also found that the Student Outcome $i$ was partially met with the 'personal responsibility for the life long learning' not met. 
Also, it was noted from the assessment that the average class performance of this smaller size class got suffered due to less participation of one or two students in the class. Hence, as a part of improving the class performance and the professionalism, the class participation should be used as a factor in the student assessment.

In addition, it will be helpful for the class if the guest speaker panel can include one or two alumni, who are in the industry as they can provide insight to the current students in transiting from the undergraduates to professionals.

\section{Recommendations:}

Hence, for the next cycle, the following actions should be considered.

1- Course outcomes should be improved by including engineering professionalism and ethics in the assessment

2- Few formal lectures, class materials and assignments should be added on engineering professionalism, ethical conduct and case studies

3- When it is possible, at least one alumnus from this institution should be included in the guest speaker panel for the EPS class so that the student can be guided with the student to professional transition.

4- Students should be motivated to have class participation and to provide the assignments on time. While the class participation is awarded with points, and a penalty should be introduced to discourage the unprofessionalism.

5- Students should be guided and advised on taking personal responsibility for learning and of the importance of life-long learning.

\begin{tabular}{l|l|}
\cline { 2 - 2 } ID No & Presentation Topics \\
\cline { 2 - 2 } PR1 & Hydropower Development \\
\cline { 2 - 2 } PR2 & Industrial Waste Management \\
\cline { 2 - 2 } PR3 & $\begin{array}{l}\text { Geostatistical Techniques in the Improvement of Spatial Modeling of Contaminated Aquatic } \\
\text { Sediments }\end{array}$ \\
\cline { 2 - 2 } PR4 & $\begin{array}{l}\text { Developing of Risk Propagation Model for Estimating Ecological Responses of Streams to } \\
\text { Anthropogenic Watershed Stresses and Stream Modifications }\end{array}$ \\
\cline { 2 - 2 } & Fracture Anisotropy Characterization in Crystalline Bedrock Using Field-Scale Azimuthal Self \\
PR5 & Potential Gradient \\
\cline { 2 - 2 } PR6 & Stream - Aquifer Interaction Assessment Using Riparian Evapotranspiration Estimates from \\
\cline { 2 - 2 } PR7 & Remote Sensing Algorithms \\
\cline { 2 - 2 } PR8 & Pareers in NRCS \\
\cline { 2 - 2 } PR9 & Reventing Ground Water Intrusion During River Flooding \\
\cline { 2 - 2 } PR10 & Environmental Engineering \\
\cline { 2 - 2 } &
\end{tabular}

\section{APPENDIX - C Instructor Course Report (ICR) for Spring 2016}

\begin{tabular}{|l|l|}
\hline Course & ENE 4440, Environmental Professionals Seminar \\
\hline Term/Year & Spring 2016 \\
\hline Faculty & \\
\hline
\end{tabular}


To measure performance, use the scales, U: Unsatisfactory, D: Developing, S: Satisfactory, and E: Excellent

$$
\mathrm{E} \geq 90 \%, 75 \% \leq \mathrm{S}<90 \%, \quad 60 \% \leq \mathrm{D}<75 \% \text { and } \mathrm{U}<60 \%
$$

To measure outcome attainment level, use the following scale with the points assigned as $\mathbf{E}=5, \mathrm{~S}=\mathbf{3}, \mathbf{D}=\mathbf{2}$ and $\mathbf{U}=\mathbf{0}$

\begin{tabular}{|l|l|l|}
\hline $\begin{array}{l}\text { AVG (5 points } \\
\text { max) }\end{array}$ & $\begin{array}{l}\text { Equivalent } \\
\text { Percentage }\end{array}$ & Recommendations \\
\hline $\mathrm{AVG} \geq 3.50$ & $\mathrm{AVG} \geq 70 \%$ & Met, no action \\
\hline $3.00 \leq \mathrm{AVG}<3.50$ & $60 \leq \mathrm{AVG}<70 \%$ & Mostly met, check conditions \\
\hline $2.50 \leq \mathrm{AVG}<3.00$ & $50 \leq \mathrm{AVG}<60 \%$ & Partially met, check conditions, analyze for correction \\
\hline $\mathrm{AVG}<2.50$ & $\mathrm{AVG}<50 \%$ & Not met, analyze and take action \\
\hline
\end{tabular}

Notes: The total enrollment in this class was 3 students.

\section{Grade distribution:}

\begin{tabular}{|l|l|l|l|l|l|l|}
\hline A & B & C & D & F & W & Total \\
\hline 2 & 0 & 1 & 0 & 0 & 0 & 3 \\
\hline
\end{tabular}

Course Outcomes

\begin{tabular}{|l|l|c|c|c|c|c|c|}
\hline \multicolumn{1}{|c|}{ Course Outcomes } & \multicolumn{1}{|c|}{$\begin{array}{c}\text { Learning } \\
\text { Measure }\end{array}$} & E & S & D & U & AVG & Attainment/Comments \\
\hline $\begin{array}{l}\text { CO-1 Be familiar with } \\
\text { practical engineering } \\
\text { operations in } \\
\text { professional setup }\end{array}$ & $\begin{array}{l}\text { Eth4, Pr1, EX- } \\
\text { Q5 }\end{array}$ & 2.67 & 0.00 & 0.00 & 0.33 & $\mathbf{4 . 4 4}$ & Met, no action needed \\
\hline $\begin{array}{l}\text { CO-2 Develop } \\
\text { engineering philosophy } \\
\text { and ethics }\end{array}$ & $\begin{array}{l}\text { ETH2, ETH3, } \\
\text { EX-Q1, EX-Q4 }\end{array}$ & 2.25 & 0.50 & 0.00 & 0.25 & $\mathbf{4 . 2 5}$ & Met, no action needed \\
\hline $\begin{array}{l}\text { CO-3 Learn to apply } \\
\text { theoretical knowledge to } \\
\text { practical works }\end{array}$ & $\begin{array}{l}\text { ETH4, Pr1, } \\
\text { PR4, EX-Q5 }\end{array}$ & 2.50 & 0.00 & 0.25 & 0.25 & $\mathbf{4 . 3 3}$ & Met, no action needed \\
\hline $\begin{array}{l}\text { CO-4 Expose to recent } \\
\text { engineering challenges } \\
\text { and concerns }\end{array}$ & Pr1, Pr4 & 2.50 & 0.00 & 0.50 & 0.00 & $\mathbf{4 . 5 0}$ & Met, no action needed \\
\hline $\begin{array}{l}\text { CO-5 Prepare students } \\
\text { for future career } \\
\text { development }\end{array}$ & $\begin{array}{l}\text { ETH2, ETH3, } \\
\text { Pr1, EX-Q1 }\end{array}$ & 2.50 & 0.50 & 0.00 & 0.00 & $\mathbf{4 . 6 7}$ & Met, no action needed \\
\hline CO-Overall Average & & & & & & $\mathbf{4 . 4 4}$ & Met, no action needed \\
\hline
\end{tabular}

ABET Student Outcomes

\begin{tabular}{|l|l|c|c|c|c|c|l|}
\hline $\begin{array}{c}\text { Performance } \\
\text { Indicator }\end{array}$ & \multicolumn{1}{|c|}{$\begin{array}{c}\text { Student Learning } \\
\text { Measure }\end{array}$} & E & S & D & U & AVG & Comments/Actions \\
\hline F1 & $\begin{array}{l}\text { ETH2, ETH3, EX-Q1, } \\
\text { EX-Q4 }\end{array}$ & 2.25 & 0.50 & 0.00 & 0.25 & $\mathbf{4 . 2 5}$ & Met, no action needed \\
\hline F2 & ETH4, EX-Q1, EX-Q4 & 2.33 & 0.00 & 0.00 & 0.67 & $\mathbf{3 . 8 9}$ & Met, no action needed \\
\hline F3 & ETH4, Pr1, EX-Q5 & 2.67 & 0.00 & 0.00 & 0.33 & $\mathbf{4 . 4 4}$ & Met, no action needed \\
\hline
\end{tabular}




\begin{tabular}{|l|l|l|l|l|l|l|l|}
\hline $\begin{array}{l}\text { F-Overall } \\
\text { Average }\end{array}$ & & & & & & $\mathbf{4 . 1 9}$ & Met, no action needed \\
\hline I1 & $\begin{array}{l}\text { ETH1,ETH2,ETH4,E } \\
\text { X-Q1,EX-Q2 }\end{array}$ & 1.8 & 0.60 & 0.00 & 0.60 & $\mathbf{3 . 6 0}$ & Met, no action needed \\
\hline I2 & $\begin{array}{l}\text { ETH3,ETH4,Pr1,EX- } \\
\text { Q1,EX-Q2, EX-Q5 }\end{array}$ & 2.33 & 0.33 & 0.00 & 0.33 & $\mathbf{4 . 2 2}$ & Met, no action needed \\
\hline I3 & Pr1,ExQ5 & 3.00 & 0.00 & 0.00 & 0.00 & $\mathbf{5 . 0 0}$ & Met, no action needed \\
\hline $\begin{array}{l}\text { I-Overall } \\
\text { Average }\end{array}$ & & & & & & $\mathbf{4 . 2 7}$ & Met, no action needed \\
\hline
\end{tabular}

\section{Faculty Evaluation:}

Two new course outcomes were incorporated (CO-2 Develop engineering philosophy and ethics \& CO-3 Learn to apply theoretical knowledge to practical works). Formal introductive lectures and course materials on engineering professionalism, ethics and management and case studies on ethical conducts were added. Grading scheme was modified to be inclusive of these student learning measures. Class discussion and attendances were also used in grading scheme. In addition, two ENE alumni who are currently working as Environmental Engineers - one in the private sector and the other in the public sector- provided guest presentations.

With the revised course outcomes, grading policy and increased number of assignments, overall performances got increased from the previous assessment cycles (2010 Fall and 2012 Fall). Course outcomes and the ABET Student Outcomes $f$ and $i$ were met with the requirements.

\section{Recommendations:}

1- The current achieved progress in this class should be maintained

2- More input on Environmental Professionals Seminar will be obtained from the Environmental Engineering Advisory Council and will be adopted accordingly into the course.

3- Students may be requested to take online training course on Responsible Conduct of Research for Engineers (RCRE) administered and assessed by Collaborative Institutional Training Initiative.

4- Introduction of Project Management components including using GANTT Chart.

\section{Student Measure Tools}

ETH - Reviews on Ethics and Engineering Professionalism related documents, videos and case studies PR - Presentations from Environmental professionals and other guest speakers EX-Q - Final Exam questions 